ку праці та роль у цьому процесі Територіальної тристоронньої соціально-економічної ради.

Організаційно-управлінське забезпечення діяльності Територіальної тристоронньої соціально-економічної ради здійснюватимуть Голова обласної ради і Голова облдержадміністрації. Нормативно-правове забезпечення діяльності цієї структури здійснюватиме Волинська обласна рада. Зі свого боку тристороння рада надаватиме найвищим органам державної влади інформацію про стан виконання стратегії збалансування попиту і пропозиції на ринку праці та пропозиції щодо удосконалення системи нормативноправового та організаційно-управлінського забезпечення у сфері соціального діалогу.

1. Волинь-2016: статистичний щорічник / За ред. В.Ю. Науменка. - Луцьк: Головне управління статистики у Волинській області, 2017. - 457 с.

2. Головне управління статистики у Волинській області : офіційний веб-сайт [Електронний pecypc]. - Режим доступу: http://www.lutsk.ukrstat.gov.ua.

3. Праця Волині-2014: статистичний збірник / За ред. Л.С. Баранюк. - Луцьк: Головне управління статистики у Волинській області, 2015. - 107 с.

4. Праця Волині-2015: статистичний збірник / За ред. В.О. Грабаровської. Луцьк: Головне управління статистики у Волинській області, 2016. - 116 с.

5. Праця Волині-2016: статистичний збірник / За ред. В.О. Грабаровської. Луцьк: Головне управління статистики у Волинській області, 2017. -103 с.

6. Праця Волині-2017: статистичний збірник / За ред. В.О. Грабаровської. Луцьк: Головне управління статистики у Волинській області, 2018. - 128 с.

*УДК 351.84

Шубалий О.М., д.е.н., професор

Андрусик I.O.

Луцький національний технічний університет

\title{
СТАН I ПЕРСПЕКТИВИ ВДОСКОНАЛЕННЯ СОЦІАЛЬНОГО ЗАХИСТУ НАСЕЛЕННЯ У РЕГІОНІ
}

У статті проведено оцінку стану і обгрунтовано перспективні напрями вдосконалення соціального захисту населення на прикладі Волинської області.

Ключові слова: соціальний захист, доходи населення, соціальні допомоги, середня заробітна плата, пенсія, регіон.

* Шубалий О.М., Андрусик І.О. 


\section{Shubalyi O., Andrusyk I.}

\section{STATUS AND PROSPECTS FOR IMPROVING SOCIAL PROTECTION OF THE POPULATION IN THE REGION}

The level of social protection of the population depends to a large extent on the level of development of the region concerned. Therefore, there is a need for additional research on the peculiarities of the formation of social protection standards at the regional level.

The purpose of the study is to study the trends of changing indicators and justification of proposals for improving social protection of the population in a separate region - Volyn region.

On the basis of the study of the dynamics of total expenditures on social protection in the Volyn region, a steady increase of $58 \%$ over the past three years has been revealed. This indicator characterizes the degree of implementation of social functions by public authorities. According to the analysis of the population, it is evident that in the last three years it has decreased by 4023 persons. This suggests inefficiency of social protection of the population. From the study of the level of the employed population, it is clear that it has decreased by $7.85 \%$, which suggests a deterioration of the situation. The main socially unprotected group of the population in the context of lowering real incomes were pensioners. After all, the average amount of pensions barely exceeds the subsistence level. A more detailed analysis of the pension provision in Ukraine shows a reduction in the real size of the pension, as well as a reduction in its share in percentage wages. In recent years, the state has been actively pursuing a policy of reducing the number of pensioners by increasing the retirement age, limiting the maximum amount of pensions and other measures that increase social tension in society.

There was a nominal increase in the living standards of pensioners. In turn, the subsistence minimum is still much lower, but it is beneficial for the state, since levels of various social expenditures are tied to this indicator. The assessment of the effectiveness of social protection of the population has shown that there are many problems that impede the normal functioning of this system. The biggest problem that exists at present is the discrepancy of social standards with the real situation, because under these circumstances, our country's inhabitants can not fully satisfy their needs and increase the flows of labor migration to the developed countries.

The solution to most of these is associated with the need for accelerated growth of the national economy, as well as the complete elimination of its shadow component, which by many estimates is about $50 \%$. That is, the de-nationalization of the national economy can become a powerful impetus for the growth of incomes and budgets of all levels of at least $25 \%$. Another important impetus of economic growth and raising the standard of living of the population and basic indicators of social protection should be the involvement in the legal money circulation of the population, which are stored by the banks, but can become a powerful tool for the growth of domestic investment, which is appropriate to direct the creation and development of production with a new added cost. This will again increase the level of employment and income of the population, as well as create a multiplier effect for the growth of social standards of living.

Key words: social protection, population incomes, social assistance, average wage, pension, region. 
Шубалый А.М., Андрусик И.О.

\section{СОСТОЯНИЕ И ПЕРСПЕКТИВЫ СОВЕРШЕНСТВОВАНИЯ СОЦИАЛЬНОЙ ЗАЩИТЫ НАСЕЛЕНИЯ В РЕГИОНЕ}

В статье проведена оценка состояния и обоснованы перспективные направления совершенствования социальной защиты населения на примере Волынской области.

Ключевые слова: социальная защита, доходы населения, социальные пособия, средняя заработная плата, пенсия, регион.

Постановка проблеми у загальному вигляді i ï̈ зв'язок 3 важливими науковими та практичними завданнями. Соціально орієнтована ринкова економіка базується на принципі соціальної справедливості, що означає, що необхідно забезпечити захист певних верств населення в країні, що самі по собі не можуть забезпечити гідний рівень життя. Держава утверджує чіткий рівень соціальних норм (склад споживчого кошика, розмір прожиткового мінімуму, мінімальну заробітну плату тощо). Рівень соціального захисту населення значною мірою залежить від рівня розвитку відповідного регіону. Тому виникає необхідність проведення додаткових досліджень щодо особливостей формування стандартів соціального захисту населення на регіональному рівні.

Аналіз останніх досліджень, у яких започатковано вирішення проблеми. Досліджуване питання розкрите в працях багатьох вітчизняних і зарубіжних науковців, зокрема таких як А. Гриненко, I. Михайловська, Т. Косова, Н. Флорескул, А. Халецька, Г. Юрчик, І. Ярошенко та багатьох інших [2-8]. Відзначивши значний внесок дослідників у розробку даної проблематики, слід зауважити, що обгрунтування ефективного застосування соціального захисту у системі соціальної політики щодо вирішення соціальних проблем у регіоні вимагає подальших досліджень.

Цілі статті. Мета дослідження полягає у вивченні тенденцій зміни показників та обгрунтуванні пропозицій щодо вдосконалення соціального захисту у Волинській області.

Виклад основного матеріалу дослідження 3 повним обгрунтуванням отриманих наукових результатів. Ступінь здійснення соціальних функцій державою можна оцінити, вивчивши динаміку 
загальних видатків на соціальний захист у Волинській області (рис. $1)$.

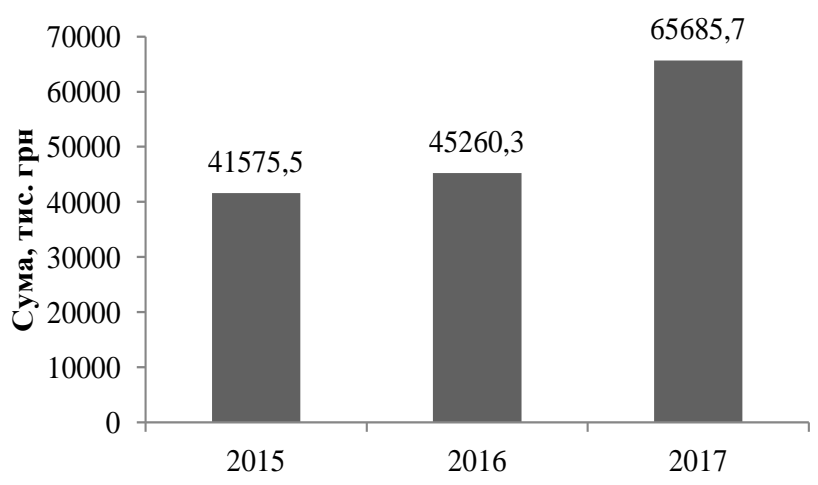

Рис. 1. Динаміка загальних видатків на соціальний захист у Волинській області за 2015-2017 рр. (побудовано за [1])

Спостерігаємо зростання видатків на соціальний захист, а саме з 41575,5 тис грн у 2015 році до 65685,7 тис грн у 2017 році, або відповідно на 58\%. Попри щорічне збільшення видатків бюджету на соціальну сферу, рівень соціального захисту населення залишається на низькому рівні. Україна переживає політичні та економічні кризи, що негативно позначається на рівні життя людей та породжує бідність серед населення. Основне завдання полягає в захисті певних найбільш уразливих категорій населення, що звичайно ж потребує фінансової підтримки.

Соціальна політика на національному та регіональному рівнях не прияють збільшення чисельності наявного та постійного населення у регіоні (рис. 2).

Як бачимо, чисельність населення даного регіону кожного року знижується. Загалом у 2017 році порівняно до 2015 роком населення зменшилося на 0,004\% (або 4023 осіб). Це зумовлено нестабільною ситуацією в країні, адже поряд із зростанням смертності населення активізувалися процеси трудової міграції. 
Економічні науки". - Серія "Облік і фінанси". - Випуск 15 (57). - 2018.

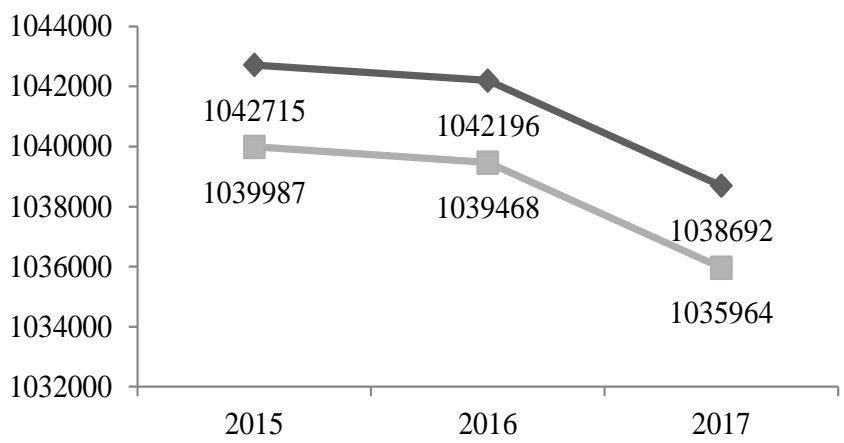

—Наявне населення, осіб - Постійне населення, осіб

Рис. 2. Динаміка наявного та постійного населення у Волинській області за 2015-2017pp. (побудовано за даними [1])

Соціальні допомоги поступово збільшуються та на фоні низької заробітної плати займають значну частку у доходах населення (табл. 1).

Таблиця 1

Динаміка зміни соціальних допомог у доходах населення Волинської області за 2014-2016 pp.

\begin{tabular}{|c|c|c|c|c|c|c|}
\hline \multirow[b]{2}{*}{ Показники } & \multicolumn{3}{|c|}{ Роки } & \multicolumn{3}{|c|}{ Темп приросту, \% } \\
\hline & 2014 & 2015 & 2016 & $\begin{array}{c}2015 / \\
2014\end{array}$ & $\begin{array}{c}2016 / \\
2015\end{array}$ & $\begin{array}{c}2016 / \\
2014\end{array}$ \\
\hline Доходи - усього, млн. грн & 27986 & 33250 & 39319 & 18,8 & 18,3 & 40,5 \\
\hline $\begin{array}{l}\text { Соціальні допомоги та } \\
\text { iнші одержані поточні } \\
\text { трансферти, млн. грн } \\
\end{array}$ & 11717 & 13752 & 15775 & 17,4 & 14,7 & 34,6 \\
\hline $\begin{array}{lrr}\text { Питома } & \text { вага } & \text { соціальних } \\
\text { допомог } & \text { у } & \text { загальних } \\
\text { доходах, \% } & \\
\end{array}$ & 41,9 & 41,4 & 40,1 & $-1,19$ & $-3,14$ & $-4,3$ \\
\hline $\begin{array}{l}\text { Наявний дохід у розрах. } \\
\text { на одну особу, грн }\end{array}$ & 20137,2 & 24222,3 & 28312,5 & 20,3 & 16,9 & 40,6 \\
\hline $\begin{array}{l}\text { Реальний наявний дохід } \\
\text { населення, млн. грн }\end{array}$ & 20985 & 25259 & 29496 & 20,4 & 16,8 & 40,6 \\
\hline
\end{tabular}

Примітка. Побудова автором на основі даних [51]. 
Протягом аналізованого періоду відбулося зростання й показника наявного доходу у розрахунку на одну особу загалом у два рази. Зменшення питомої ваги соціальних допомог у доходах населення, відповідно з 41,9\% до 40,1\%, відбувалося в умовах знецінення національної валюти. Тобто соціальні стандарти зростали меншими темпами, ніж відбувалося зростання інфляції.

Таким чином соціальні допомоги не виконували функції належного соціального захисту населення, особливо для осіб, які не мали додаткових доходів.

Це вимагає детальнішого вивчення структури соціальних виплат за основними видами (рис. 3).

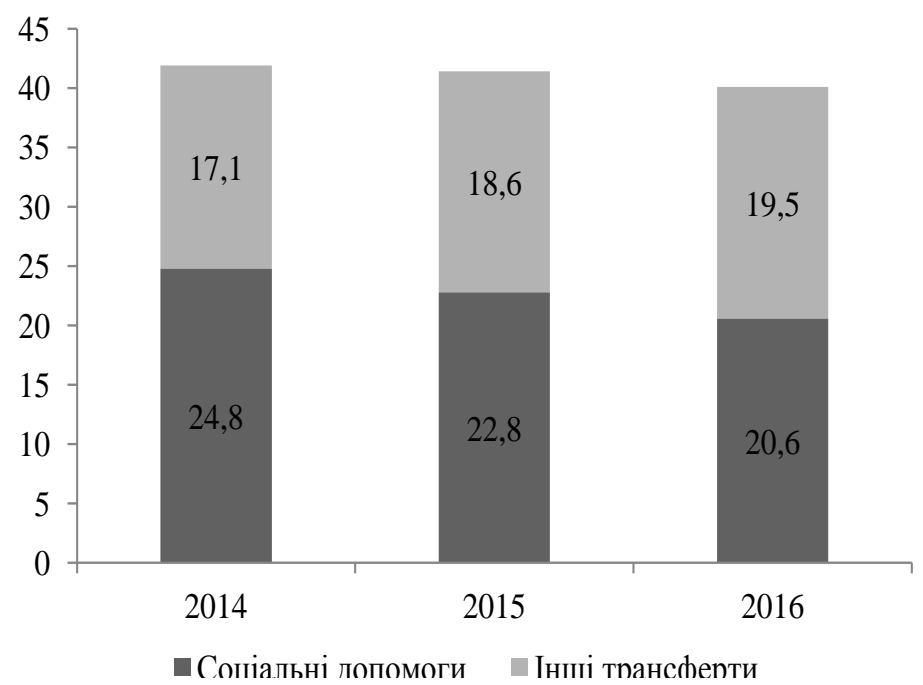

Рис. 3. Структура соціальних виплат за основними видами у Волинській області за 2014-2016 рр., \% (побудовано за [1])

За аналізований період спостерігаємо незначне зменшення питомої ваги соціальних допомог - 3 41,9\% у 2014 році до 40,1\% у 2016 році, але їх частка залишається найбільшою в структурі доходів населення.

Певним результатом соціальної політики є зміна показників економічної активності, зайнятості і безробіття населення (табл. 2). 
Економічні науки". - Серія "Облік і фінанси". - Випуск 15 (57). - 2018.

Таблиця 2

Рівень зайнятого та безробітного населення у Волинській області за 2015-2017 pp.

\begin{tabular}{|c|c|c|c|c|c|}
\hline \multirow{2}{*}{ Рік } & \multirow{2}{*}{$\begin{array}{c}\text { Економіч- } \\
\text { но активне } \\
\text { населення, } \\
\text { тис осіб }\end{array}$} & $\begin{array}{c}\text { Зайняте населення } \\
\text { в серед- }\end{array}$ & $\begin{array}{c}\text { Безробітне населення } \\
\text { (за методологісю МОП) } \\
\text { економіч- } \\
\text { тис осіб }\end{array}$ & $\begin{array}{c}\text { но } \\
\text { активного } \\
\text { населення }\end{array}$ & $\begin{array}{c}\text { В середньо- } \\
\text { му, тис осіб } \\
\text { економіч- } \\
\text { но } \\
\text { активного } \\
\text { населення }\end{array}$ \\
\hline 2015 & 432,9 & 389,8 & 90,0 & 43,1 & 10,0 \\
\hline 2016 & 426,3 & 376,6 & 88,3 & 49,7 & 11,7 \\
\hline 2017 & 413,5 & 361,4 & 87,4 & 52,1 & 12,6 \\
\hline
\end{tabular}

Примітка. Побудова автором на основі даних [1].

Найбільше на таку ситуацію впливає погіршення становища в системі охорони здоров'я, збільшується кількість осіб з інвалідністю в працездатному віці. Рівень безробітного населення 3 кожним роком зростає, відповідно рівень зайнятого населення зменшується, у 2017 році на 28,4 тис осіб, або 7,85\%, що свідчить про погіршення соціального становища населення.

Певним індикатором рівня виконання заробітною платою стимулюючої функції є співвідношення іiї середнього рівня до рівня мінімальної заробітної плати (рис. 4). Видно, що номінальна заробітна плата за останні роки зростала, а саме у 2017 році на 2428 грн або на 73,8\% у порівнянні до 2015 року. Нарахована заробітна плата у \% до мінімальної у 2017 році знизилась на 93,5\% до 2016 року. На зростання найбільше вплинуло збільшення рівня мінімальної заробітної плати, але фактичний розмір у відповідності до мінімального рівня значно знизився. Підвищення рівня доходів усіх верств населення сприяло покращенню ситуації з бідністю. Вперше з 2013 року зафіксовано суттєве зменшення рівня абсолютної бідності. 


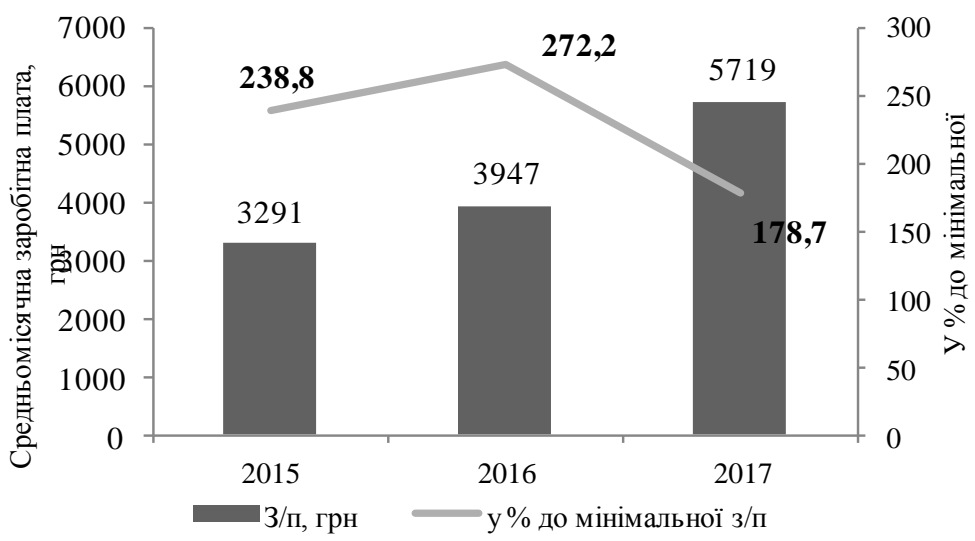

Рис. 4. Середньомісячна зарплата одного працівника у Волинській області за 2015-2017 pp. (побудовано за [1])

Чисельної соціально незахищеною верствою населення $є$ пенсіонери, що потребує вивчення ситуації у цій сфері (табл. 3).

Таблиця 3

Співвідношення середнього розміру призначених місячних пенсій

та прожиткового мінімуму у Волинській області за 2015-2017 pp.

\begin{tabular}{|c|c|c|c|c|c|c|}
\hline \multirow[b]{2}{*}{ Показники } & \multicolumn{3}{|c|}{ Роки } & \multicolumn{3}{|c|}{ Темп приросту, \% } \\
\hline & 2015 & 2016 & 2017 & \begin{tabular}{|l|}
$2016 /$ \\
2015
\end{tabular} & $\begin{array}{ll}2017 / \\
2016\end{array}$ & $\begin{array}{l}2017 / \\
2015\end{array}$ \\
\hline $\begin{array}{l}\text { Прожитковий мінімум на одну } \\
\text { особу в розрах. на місяць, грн }\end{array}$ & 1330 & 1544 & 1624 & 16,1 & 5,2 & 22,1 \\
\hline $\begin{array}{l}\text { для осіб, які втратили працез- } \\
\text { датність }\end{array}$ & 1074 & 1247 & 1312 & 16,1 & 5,2 & 22,1 \\
\hline $\begin{array}{l}\text { Середній розмір призначених } \\
\text { місячних пенсій пенсіонерів, які } \\
\text { перебувають на обліку в органах } \\
\text { Пенсійного фонду, грн }\end{array}$ & 1392,8 & 1511,9 & 1664,3 & 8,5 & 10,1 & 19,5 \\
\hline $\begin{array}{l}\text { Розмір пенсії у \% до прожит- } \\
\text { кового мінім. на } 1 \text { особу }\end{array}$ & 104,7 & 98 & 102,5 & $-6,4$ & 4,6 & $-2,1$ \\
\hline $\begin{array}{l}\text { Розмір пенсії у \% до прожит- } \\
\text { кового мінімуму для осіб, які } \\
\text { втратили працездатність }\end{array}$ & 129,7 & 121,2 & 126,8 & $-6,5$ & 4,6 & $-2,2$ \\
\hline
\end{tabular}

Примітка. Побудова автором на основі даних [51]. 
Загалом можна зазначити, що відбувається постійне зростання загального прожиткового мінімуму і також для осіб, які втратили працездатність в цілому за аналізований період на 22,1\%. За цей період середній розмір призначених місячних пенсій пенсіонерів, які перебувають на обліку в органах Пенсійного фонду, зріс на 19,5\%. Але за 2015-2016 рр. ці показники зросли, відповідно на $16,1 \%$ та 8,5\%, тобто розміри пенсії зростали меншими темпами, ніж прожиткового мінімуму. Таким чином, відбулося номінальне підвищення рівня життя пенсіонерів. Показник прожиткового мінімуму залишається значно заниженим, але це вигідно для держави, оскільки до його рівня прив'язуються рівні різноманітних соціальних видатків.

Висновки. На основі вивчення динаміки загальних видатків на соціальний захист у Волинській області виявлено поступове їх зростання за останні три роки на 58\%. Згідно проведеного аналізу чисельності населення видно, що за останні три роки воно зменшилось на 4023 особи. Це говорить про неефективність соціального захисту населення.

3 дослідження рівня зайнятості населення, видно, що він зменшився на 7,85\%, тобто відбулося погіршення ситуації. Основною соціально незахищеною групою населення в умовах зниження реальних доходів стали пенсіонери. Адже середній розмір пенсій ледве перевищує рівень прожиткового мінімуму. Детальніший аналіз стану пенсійного забезпечення в Україні свідчить про зменшення реального розміру пенсії, а також зменшення ії частки у процентах до розміру заробітної плати. Протягом останніх років держава проводить активну політику зменшення кількості пенсіонерів за рахунок підвищення пенсійного віку, обмеження максимального розміру пенсії та інші заходи, що збільшує соціальну напругу у суспільстві.

Оцінка ефективності соціального захисту населення показала, що існує багато проблем, які перешкоджають нормальному функціонуванню даної системи. Найбільшою проблемою, яка існує на даний час $є$ невідповідність соціальних стандартів реальній ситуації, адже за даних обставин жителі нашої країни не можуть повністю задовольнити свої потреби та збільшують потоки трудової міграції у розвинені країни. 
Вирішення більшості з вказаних пов'язується з необхідністю забезпечення прискореного зростання національної економіки, а також повного усунення іiї тіньової складової, яка за багатьма оцінками складає близько 50\%. Тобто детінізація національної економіки може стати потужним імпульсом зростання доходів населення та бюджетів усіх рівнів не менш як на 25\%. Також важливим імпульсом економічного зростання та підвищення рівня життя населення й базових показників соціального захисту повинно стати залучення в легальний грошовий оборот коштів населення, які зберігаються паза банками, але можуть стати потужним інструментом зростання внутрішніх інвестицій, які доцільно спрямувати на створення й розвиток виробництв з новою доданою вартістю. Це дозволить знову ж підвищити рівень зайнятості та доходів населення, а також створить мультиплікативний ефект для зростання рівня соціальних стандартів життя населення.

1. Головне управління статистики у Волинській області : офіційний веб-сайт [Електронний pecypc]. - Режим доступу: http://www.lutsk.ukrstat.gov.ua/

2. Гриненко А. М. Вплив соціальної політики на соціальну згуртованість суспільства / А. М. Гриненко, В. В. Кирилюк // Соціально-трудові відносини: теорія та практика. - 2016. - № 2. - С. 130-135.

3. Михайловська I. М. Система соціального захисту населення в Україні: сутність, основні складові та напрямки вдосконалення / І.М. Михайловська, О.В. Неліпович. // Вісник Хмельницького національного університету. - 2011. - С. 255-260.

4. Косова Т. Д. Сутність і критерії ефективності системи соціального захисту / Т. Д. Косова, І. В. Басанцов // Фінанси України. - 2000. - № 8. - С. 26-32.

5. Москаленко В. В. Сутність соціального захисту та його місце в політиці соціальної держави / В. В. Москаленко // Наукові записки. - 2003. - Т. 21. - С. 4144.

6. Флорескул Н. Система соціального захисту населення як чинник формування соціальної держави / Н. Флорескул. // Вісник Київського національного торговельно-економічного університету. - 2009. - №2. - С.34-45.

7. Халецька А.А. Методологічні передумови формування політики соціального захисту населення / А. А. Халецька // Вісник Академії митної служби України. Сер.: Державне управління.. - 2010. - № 1. - С. 75-80.

8. Юрчик Г. Соціальний захист зайнятого населення України в умовах економічної нестабільності / Г. Юрчик // Україна: аспекти праці. - 2015. - № 1. - С. 3442. 